Discussion

Papers
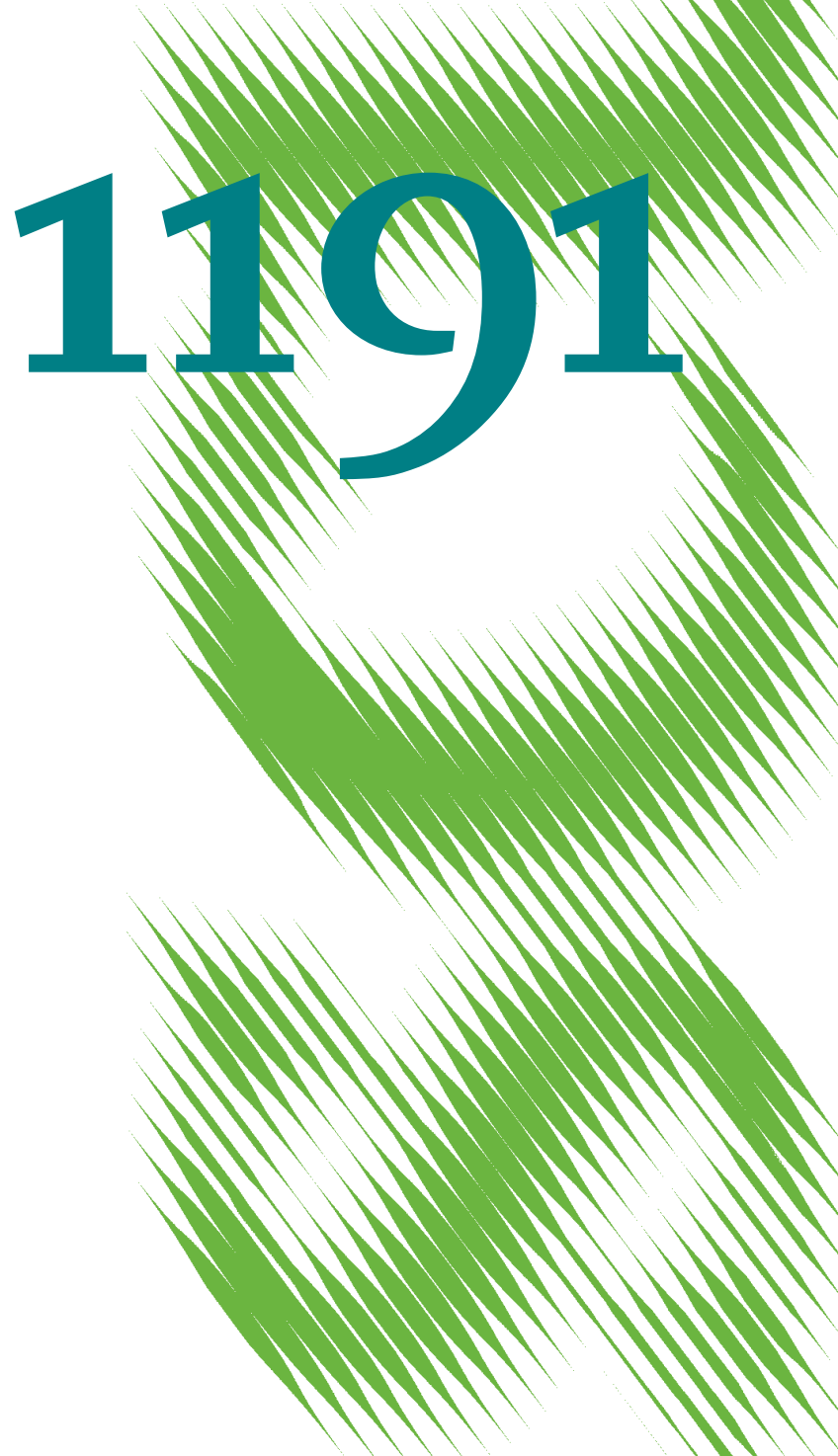

Internet-Based Hedonic Indices of Rents and Prices for Flats

Example of Berlin 
Opinions expressed in this paper are those of the author(s) and do not necessarily reflect views of the institute.

IMPRESSUM

(C) DIW Berlin, 2012

DIW Berlin

German Institute for Economic Research

Mohrenstr. 58

10117 Berlin

Tel. $+49(30) 89789-0$

Fax +49 (30) $89789-200$

http://www.diw.de

ISSN print edition $1433-0210$

ISSN electronic edition 1619-4535

Papers can be downloaded free of charge from the DIW Berlin website:

http://www.diw.de/discussionpapers

Discussion Papers of DIW Berlin are indexed in RePEc and SSRN:

http://ideas.repec.org/s/diw/diwwpp.html

http://www.ssrn.com/link/DIW-Berlin-German-Inst-Econ-Res.html 


\title{
Internet-based hedonic indices of rents and prices for flats Example of Berlin
}

\author{
Konstantin A. Kholodilin* Andreas Mense ${ }^{\S}$
}

February 28, 2012

\begin{abstract}
In this paper, we suggest to estimate the home rents and prices in German regions/cities using the data from Internet ads offering the housing for rent and sale. Given the richness of information contained in the ads, we are able to construct the quality-adjusted rent and price indices using the hedonic approach. The results can be applied both for investigating the dynamics of rents/prices and for examining their distribution by city districts or regions.
\end{abstract}

Keywords: Internet ads; home rents; home prices; German regions; Berlin; hedonic approach.

JEL classification: C21; O47; R11.

*DIW Berlin, Mohrenstraße 58, 10117 Berlin, Germany, e-mail: kkholodilin@diw.de

${ }^{\S}$ Friedrich-Alexander-Universität Erlangen-Nürnberg, Kochstraße 4, 91054 Erlangen, Germany, e-mail: andreas.mense@wiwi.phil.uni-erlangen.de

T The authors would like to thank Simon Junker and Tatjana Ribakoff for their useful comments. 


\section{Contents}

1 Introduction $\quad 1$

2 Overview of home rent/price indices in Germany 1

2.1 Home rents . . . . . . . . . . . . . . . . . . . . 1

2.2 Home prices . . . . . . . . . . . . . . . . . . . . . 3

3 Data $\quad 4$

4 Hedonic regressions $\quad 6$

5 Conclusion $\quad 11$

$\begin{array}{ll}\text { References } & 11\end{array}$

$\begin{array}{ll}\text { Appendix } & 14\end{array}$ 


\section{List of Tables}

1 Comparison of the three databases: Immobilienscout24, Immonet, and Immowelt. Correlation with population of NUTS1 regions, July 2011 . . . . . 14

2 List of variables from housing ads . . . . . . . . . . . . . . . . 15

3 Descriptive statistcs of ads offering flats for rent and sale . . . . . . . . . 16

4 Results of hedonic regression for the flats rents in Berlin, 2011:6-2012:2 . . . 17

$5 \quad$ Results of hedonic regression for the flats prices in Berlin, 2011:6-2012:2 _ . 18

\section{List of Figures}

1 Distribution of quality-adjusted rent for flat by Berlin's districts, February 201219

2 Distribution of quality-adjusted price for flat by Berlin's districts, February

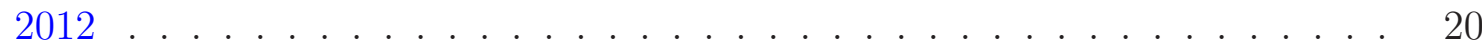

3 Dynamics of rents and prices for flats in Berlin-Mitte, June 2011 - February

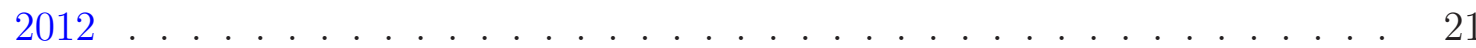





\section{Introduction}

After decades of stagnating real house prices (see, e.g., Kholodilin et al. (2010)) in Germany, the general public started to worry about the possibility of a speculative bubble in German housing market ${ }^{1}$. These fears mostly base upon anecdotical evidence rather than upon the statistical data.

Unfortunately, the home rent and price statistics in Germany, especially at the regional level, is far from being perfect. It covers too short a period, has too high aggregation level both in terms of frequency and geography. Thus, to dissipate or to confirm the bubble fears, one needs improved statistical data. The objective of this paper is to fill this gap by developing home rent/price indices that can be regularly updated, produced at monthly or even higher frequency, and interpolated at virtually any level of geographical disaggregation. As an example a set of rent/price indices is suggested for Berlin. However, the methodology described here can be easily extended to other cities or regions of Germany.

The paper is structured as follows. In section 2, the existing rent and price indices for Germany are discussed. Section 3 describes the data used in the study. In section 4, the approach to computing the home rent/price indices is explained and results are discussed. Finally, section 5 concludes.

\section{Overview of home rent/price indices in Germany}

There are several home price and rent indices available for the German market that use a variety of data sources and methods. The discussion below is based on Hoffmann and Lorenz (2006), Georgi and Barkow (2010), and Schürt (2010).

\subsection{Home rents}

The official home rent index is a part of the consumer price index produced by the German Federal Statistical Office (Destatis) that obtains rents from the survey on the costs of living of private households. The index for basic rents is available at a monthly frequency and on

\footnotetext{
${ }^{1}$ See, for example, the following journal and newspaper publications: Hajek and Krumrey (2011), Uken (2011), and hei/dpa (2011), among others.
} 
NUTS1 level, but not for Bremen, Hamburg, and Schleswig-Holstein, see Destatis (2003). About 15,000 dwellings belong to the panel, where 5,000 rents are updated each month so that each apartment reports their rent once a quarter, see Schürt (2010).

Hoffmann and Kurz (2002) discuss the German market for rental housing and criticize existing measures of rent prices for their lack of quality adjustment, disaggregation, and representativeness. They themselves develop an index based on the Socio-Economic Panel (SOEP) maintained by the DIW Berlin, which is a yearly household survey. Hoffmann and Kurz criticize the matched-model approach of the German CPI since quality changes of one single apartment over time may lead to serious distortions in the price index.

Empirica AG publishes an index of rents based on data from IDN Immodaten GmbH, starting in 2004:Q1. The index uses offered rents collected from a variety of Internet pages and newspapers. Hedonic indices, median prices, and variances are reported annually and quarterly. Based on the hedonic price indices, Empirica also compiles a city ranking.

The F+B market monitor uses essentially the same data sources and publishes similar rent indices as Empirica. However, the number of yearly observations exceeds that of Empirica (4 million against 1.4 million in total for rents and prices), which is why a monthly publication of the index is feasible. Both Empirica and $\mathrm{F}+\mathrm{B}$ indices are available for a fee only.

The third index based on IDN data is published by the Federal Institute for Research on Building, Urban Affairs, and Spatial Development (BBSR), starting in 2007. BBSR calculates median rents and observations are classified according to the structural and economic characteristics of the community they are situated in. Filters to identify "typical cases" are applied to adjust for quality differences, see Schürt (2010).

Mietspiegel indices (MI) are available for larger as well as smaller cities. Since 2001, quality-adjusted MI have to fulfill certain legal requirements (German Civil Code, §558 BGB) and are usually issued at yearly frequency. It is up to the cities themselves whether the effort is made to create a MI, see BBR (2002).

BulwienGesa AG publishes yearly indices based on data from offered rents and prices, expert committee evaluations, and MI, starting in 1986. Data are collected in 125 cities from 1990 on and several market segments are reported separately. However, rents and prices are merged into one composite index, see Hampe and Wenzel (2011). 


\section{$2.2 \quad$ Home prices}

The Bundesbank compiles a price index for residential housing. The data for this index are provided by BulwienGesa AG. Due to the use of different types of data sources, the Bundesbank index seems to be able to overcome some of the shortfalls of indices based on a single data source. However, the index is compiled from 125 cities only which may lead to underrepresentation of rural areas. The index considers "typical cases" in the categories "apartments" (70 $\mathrm{m}^{2}$ large) and "townhouses" (100 $\mathrm{m}^{2}$ large) that satisfy a certain standard of living and are located in medium to high quality neighborhoods. New and existing buildings are dealt with separately, but rented housing and sales are merged into one composite index. BulwienGesa's own index family also includes prices for residential housing, office buildings, and land cost. The indices are updated yearly since 1975, which makes the time series the longest available for the German market, see Hampe and Wenzel (2011).

Destatis publishes hedonic price index for one- and two-family turnkey houses and flats at quarterly frequency (Behrmann and Kathe (2004), Dechent (2008)). It starts in 2000, covers seven NUTS1 regions, and is included as a partial index - together with price indices for selfmade and prefabricated houses - in the house price index for newly constructed homes. New and existing houses are treated separately. Data are collected from local expert committees and include a variety of quality variables. As a consequence, the number of observations is rather low, with approximately 40,000 cases per year. The index of the construction sector also includes - among others - Laspeyres subindices for newly built homes and office buildings. Data is collected from approximately 5,300 construction firms on a quarterly basis. With some exceptions, indices are also available from 1958 on at a yearly frequency, see Destatis (2011).

The Hypoport index HPX based on credit transactions for apartment buildings and family houses starts in August 2005, (cf. Dübel and Iden 2008, 2010). It is updated monthly and consists of an overall index as well as three subindices for apartments, new houses, and existing houses. Hypoport uses a two-step hedonic regression: First, square meter prices are adjusted for quality via hedonic regression. The residuals of this regression are taken as proxies for the location of the building. Based on these proxies, tercile location dummies are created and a second regression is used to determine the location-adjusted price. Spatially, 
HPX covers 16 metropolitan areas for houses and 7 for apartments, with around 45,000 observations yearly.

The indices of vdp Research $\mathrm{GmbH}$ are also transaction based, where a total of 500,000 observations were used from 2003 to 2010. The yearly number of cases is thus slightly greater than the HPX and Destatis figures. Depending on regional data availability, vdp calculates quarterly, semi-annual, and annual price trends for the sub-markets owner-occupied houses, apartments, and office buildings. Extensions to store areas and rented residential buildings are planned according to the vdp homepage ${ }^{2}$.

There are several indices based on the Internet offer prices for homes. Empirica uses IDN data from online and newspaper offers to construct quarterly indices with a high level of disaggregation, starting in 2004. Obviously, these prices may differ from transaction prices but are available with a very short lag of about four weeks. The F+B market monitor applies a similar methodology. The F+B indices are updated quarterly for houses and apartments. Both providers use hedonic regression to adjust for quality differences. Due to the high number of observations, $\mathrm{F}+\mathrm{B}$ are able to calculate price trends for most ZIP code areas separately in order to avoid that global trends shadow local developments. The BBSR index that is also based on IDN data with 1.4 million cases yearly is updated semi-annually.

Several OECD studies (Girouard et al. (2006) and Rousová and van den Noord (2011)) use a quarterly house price index for Germany as a whole. This index is constructed from the annual house price index for Germany and quarterly house price indices for the seven largest cities, both of which are provided by the Bundesbank. The interpolated quarterly price is obtained by minimizing the deviations between the two indices subject to a restriction that the summation of the resulting quarterly values within each year must be equal the corresponding value of the annual index ${ }^{3}$.

\section{Data}

This study uses data contained in the Internet ads on flats offered for rent and for sale in Germany. The data have been downloaded from three popular German real-estate websites:

\footnotetext{
2 http://www.vdpresearch.de

${ }^{3}$ This information was kindly provided to the authors by Christophe André from the OECD.
} 
Immobilienscout24.de, Immonet.de, and Immowelt.de, where housing ads are published.

There are, of course, other sites, where such ads are placed. However, due to their high market shares, these three sites are representative to a high degree. For example, in January 2012, the number of ads offering flats and houses for rent and sale in Immobilienscout24.de $(385,000)$, Immowelt.de $(387,000)$, and Immonet.de $(247,000)$ was 919,000 in total. Their closest competitors are Quoka.de (160,600), Immobilien.de (79,200), and Kalaydo.de $(50,700)$. Given these figures, the three websites have a combined market share of approximately $74 \%$.

Table 1 reports the correlation between population in 2010 by German NUTS1 regions and the total number of ads. The representativeness of the data seems to be lower for one single website and market segment as compared to the three websites taken together, in which case the correlation exceeds 0.91 in three of the four segments. This also shows the importance of using more than one website as the data source. The total correlation of ads per region in all market segments and the population is as high as 0.96 . The low figures for rental flats can be explained by the overproportionate number of ads placed in Sachsen. While only $5 \%$ of the total population live in Sachsen, its Immonet share exeeds $21 \%$ for rental flats. To a lesser extent, the same is true for Immobilienscout24 (16\%), and Immowelt $(9 \%)$.

Given their size and representativeness, we decided to use data from the three sources mentioned above: Immobilienscout24, Immowelt, and Immonet. The ads published on the three websites name numerous characteristics of the housing property which are listed in Table 2. These characteristics as well as price information was extracted from the ads. The fact that there might be overlapping ads in different websites diminishes the marginal benefit of additional (and considerably smaller) websites. Three different sources thus seem to be a reasonable choice. Notice also that the number of ads placed on the three websites is much greater than the size of the microcensus sample covering 400,000 respondents, even if duplicate ads are removed.

Since it is very likely that some ads are published on different websites simultaneously, these duplicates may lead to serious distortions of the results. We therefore designed a matching algorithm in order to minimize the number of duplicates. For more details on the algorithm see Kholodilin and Mense (2011). 
All Internet ads without exception, however, can hardly be used to compute the price indices. The reason is that many of the objects, especially flats offered for sale are not constructed yet and such ads are placed by the construction firms in order to attract new customers. Hence, a substantial part of these flats exist only on paper and may never be built. Not accounting for this would lead us to biased results. Therefore, we identified the new flats by taking advantage of the information contained in the ads. In short, this is done by identifying both the ads, which have explicit information on whether the flats are new or not (future or current year as construction year, search categories "new" and/or "under construction") and those, whose text contains certain keywords that implicitly indicate that the flats are new. The resulting variable "New" is the probability that the flat is really new. For more details on this algorithm see Kholodilin and Mense (2011).

Table 3 presents descriptive statistics on flats for rent and for sale. These allow drawing a picture of a "typical" flat. It can be noticed that the flats for sale are generally larger and better equipped than the flats for rent. The flats for sale are on average $87 \mathrm{~m}^{2}$ large and have 2.8 rooms versus $72 \mathrm{~m}^{2}$ and 2.5 rooms in flats for rent. A much larger proportion of flats for sale have cellar, parking lots, and guest WC than the flats for rent. A fitted kitchen is less widespread in the flats for sale. But this can be explained by the desire of the homeowners who occupy their flats to have their own kitchen, which fits better their tastes. The distribution of flats for sale and for rent by the floor and type of flat is very similar. Flats located between 1st and 5th floor and belonging to the type "Etagenwohnung" by far and large dominate all other categories. The distribution by construction year, however, is very different. In particular, many more flats for sale belong to the category "Construction year: after 2000" than flats for rent: $22 \%$ vs. 3\%, respectively. This reflects the above mentioned tendency of construction firms to advertized themselves by placing "fake" ads of the flats that are either under construction or are even not built yet.

\section{Hedonic regressions}

The home rent/price indices we suggest here are based on the hedonic regression approach. This approach allows the quality adjustment of the rents and prices. This is necessary because each month the composition of the sample may be different. Say, in one month 
more cheap flats with low quality amenities are offered for sale, whereas the next month several luxury flats appear on the market. Without quality adjustment one would conclude that the price suddenly jumped up. This leads to wrong conclusions and a too volatile price index, which is not desirable.

The methodology of hedonic price indices is described in Maurer et al. (2004), Demary (2009), and Nappi-Choulet and Maury (2009). In short, it implies regressing the rent or price on a set of variables, reflecting the quality and location as well as other characteristics of the flat, which are relevant for the price-setting. The coefficients of the regression capture the separate contributions of each of the characteristics to the rent or price of flat. Given these coefficients and keeping flat's characteristics constant, one can obtain a quality-adjusted rent or price.

For our estimation we use the data downloaded from the three largest German Internet sites advertizing the real estate. The data were collected over the period from June 2011 through February 2012 and thus our time dimension includes 9 points. This is relatively few for an index. Still, it allows to grasp the latest tendencies on the housing market. Of course, as new data come, it is possible to extend the index.

The estimation results for rents and prices for flats in Berlin are reported in Table 4 and Table 5, correspondingly. Both regressions include a wide range of variables, such as, area of flat, number of rooms, the floor in which the flat is located, availability of a fitted kitchen, cellar, elevator, guest WC, and number of parking lots, whether the flat is equipped for elderly, construction year, type of flat, time dummies, and ZIP code dummies. The time dummies capture the changes in rents/prices over time. The ZIP code dummies approximate the geographical location of the flat within the city. In case of flats for sale (Table 5), three additional variables turned out to be significant: 1) whether the flat is rented out; 2) whether the house, in which the flat is located, is on the list of architectural monuments; and 3) whether the flat is newly built or being under construction.

The sample size, $N$, is 37,618 observations for flats for rent and 53,409 observations for flats for sale. The number of regressors (excluding constant), $K$, is 227 and 230, respectively. The vast majority (190) of the explanatory variables are the ZIP code dummies.

The results are, overall, in line with expectations about the value of a flat: Souterrain flats are significantly cheaper, whereas rather unconventional dwellings such as maisonette 
apartments, penthouses, and lofts seem to be most expensive on average. The year of construction dummies also show a coherent picture, with rising prices for newer buildings. The exception are houses that were constructed prior to 1940: Flats in these buildings are significantly more expensive than flats from the periods 1940-1960 and 1960-1990. Somewhat surprisingly, flats that are suited for handicapped persons or elderly seem to be less expensive on average, albeit the latter is not statistically significant.

Interestingly, the results for flats for sale (Table 5) are very similar. There are two major differences. Firstly, the significance of the coefficients at the variables measuring the size of the flat are different. In case of flats for rent, the flat's area has a non-linear effect on the rent per square meter: the price decreases up to certain size of flat and then goes up. In case of flats for sale, the area of a flat is irrelevant for the price for $m^{2}$. Secondly, the coefficient of variable "Elevator" is different for two markets. In case of flats for rent its effect is insignificant, whereas in case of the flats for sale it is highly significant. This probably reflects the fact that in Germany the housing is bought usually just once in life and must therefore meet the requirements that might emerge in the future, when the buyer will get older.

In addition, in case of flats for sale, the fact that a flat is rented out exerts a negative impact on its price. This can be explained by a relatively high protection of the tenants by German law. The possibilities for rent increases are quite limited. Moreover, kicking off an undesirable tenant by the landlord is not that easy in Germany. All these negatively affect the profitability of renting a flat out and thus diminished its price.

Given the large number of ZIP codes (about 200) we opt for showing only two parameter estimates: the largest and the smallest one. The largest ZIP code coefficient is obtained in case of 10117 (flats for rent) and 10115 (flats for sale), which are located in the center of East Berlin, where the real estate must be really expensive. The lowest coefficients are observed for the ZIP codes 12627 (flats for rent) and 12629 (flats for sale), which belong to the district Hellersdorf, located in the north-eastern periphery of the city.

The goodness of fit of both regressions is relatively high. The adjusted $R^{2}$ is 0.65 for flats for rent and 0.62 for flats for sale. The remaining one third of variation could not be explained using the available information. It may reflect the characteristics, which are difficult to figure out from the ads, e.g., social infrastructure, criminality. Sometimes even 
flats located in the same building can cost differently. Moreover, the error term may include the subjective valuation of the flats by their sellers. Given the lack of price information, the owners may have a wrong idea of what their property is really worth. This, of course, inflates the unexplained part of variation.

The quality-adjusted rent was computed using the estimated coefficients and characteristics of a typical flat. Namely, it was calculated for a flat having an area of 70 square meters, 3 rooms, which is located between the 1st and 5th floor, possessing a cellar, not equipped for handicapped persons or elderly, without fitted kitchen, elevator, guest WC, parking lot, or right for garden use, constructed between 1960 and 1990, belonging to the type "Etagenwohnung". In case of flats for sale, the same characteristics are kept ${ }^{4}$ and three additional characteristics are: 1) not rented out, 2) not a monument, 3) not a new one.

Using the fitted values of rents/prices by ZIP codes we were able to calculate the flats' rents/prices by districts. The district rents/prices were computed as weighted averages of the ZIP code rents/prices. As the weighting factor the number of observations per ZIP code was used. For instance, for the district Charlottenburg 23 ZIP codes. The weights then are the proportions of Internet ads placed for each of these ZIP codes in the total number of shares placed for the district. In some cases, when neighboring districts share ZIP codes, the rents or prices for the common ZIP codes are included in the home rent or price calculation of all the districts, to which they belong.

The distribution of quality-adjusted flats' rents/prices by districts is shown in Figure 1 and Figure 2, respectively. The human figures are proportional to the number of ads per each district. The largest number of ads is placed for the central districts, in particular, Charlottenburg. In the peripheric districts, the number of ads is relatively small. It is interesting that the pattern is not always the same across the two markets: flats for rent and flats for sale. For instance, in Marzahn, there are quite a few flats for rent, whereas the market of flats for sale is virtually inexistent. This is due to the fact that after the re-unification of Germany, the housing in East Germany was not privatized by selling out or granting the flats to the tenants living in them, as it was done in some former socialist countries, but concentrated in hands of the housing cooperatives that own large packages of

\footnotetext{
${ }^{4}$ This is done in order to make the results comparable across both markets. Although it is known from Table 3 that flats for rent and for rent are quite different.
} 
flats and rent them out.

The intensity of color reflects the magnitude of rent or price. The darker the color, the higher the flat rent or price. The most expensive flats - both in terms of rent and price are located in the central parts and in the west of the city. The fact that the flats in the center are relatively more expensive is characteristic for many cities. The higher rents and prices for flats in West Berlin reflect in part the legacy of the past, because for decades the city was physically split in two parts, each under a different economic and political system. Moreover, it may reflect the nice natural environment in the west, with its lakes and forests.

Figure 3 depicts the dynamics of rents and prices for flats in the central district of Berlin "Mitte". The same trajectory would be observed in all other districts, given the restriction imposed in our hedonic regressions that the time dummies are identical across ZIP codes. According to our results, the rents increased over 2011:6-2012:2 by 7.0\%, whereas the prices went up by $10.5 \%$. This corresponds to the annualized growth rate of $9.5 \%$ and $14.2 \%$. The overall price level increased from December 2010 to December 2011 in Berlin by 2.2\%. Thus, in real terms, the flats rents (prices) went up by $7.3 \%$ (12.0\%), which is quite high, given the stagnation of German real estate market in the previous decades. However, this is hardly a reason to speak about an ensuing speculative bubble at the Berlin's housing market. This might be simply an adjustment of the long time undervalued real-estate rents and prices in Berlin to the level supported by fundamental factors, such as, for example, the income.

It is also worth noticing that the home rents increased strongly in the very beginning of the sample and then stabilized at a growth rate of about $0.5 \%$ per month. The flats prices took up later, in fall 2011, and have been growing since then relatively strongly, with the monthly growth rate exceeding 1\%. In February 2012, however, they lost their momentum and stagnated.

The average home price-to-rent ratio, which is computed as $\frac{P}{12 \times R}$, where $P$ is the price per $m^{2}$ and $R$ is the rent per $m^{2}$, exceeds 19. It means that in 19 years a tenant pays out to the landlord the complete value of the flat he rents. Across different districts this ratio varies quite substantially: between 14 and 25. The ratio is higher in the districts with higher flats prices, reflecting a higher dispersion of prices than rents. Overall, given the tendency depicted in Figure 3, the price-to-rent ratio is increasing over time. 


\section{Conclusion}

In this paper, we constructed estimates of flats' rents and prices for Berlin using the data from Internet ads offering the housing for rent and for sale. Given the richness of information contained in the ads, we were able to construct quality-adjusted rents and prices using the hedonic approach. As an example we computed the home rent and price levels for Berlin for the period June 2011 — February 2012. The approach permits us both comparing the intra-city differences in rents and prices and their trajectories over time.

This technique can be easily extended to other German cities. The resulting figures can be used for monitoring the regional housing markets and examining the geographical distribution of rents and prices for flats. In addition, they can be utilized as an input for the early warning systems allowing to detect the emerging speculative bubbles. Moreover, the cumulation of the amount of available data will enable the forecasting of home rents and flats.

The advantages of our flats' rent and price indices are fourfold. First, the data are readily available and therefore the publication lag of the indices can be reduced to a minimum. Second, the indices can be issued at a relatively high frequency. Third, the data allow a very deep geographical differentiation of rents and prices. Last but not least, the indices we construct can be obtained free of charge, unlike those produced by the competing institutions.

\section{References}

BBR (2002). Hinweise zur Erstellung von Mietspiegeln. Technical report, Bundesministerium für Verkehr, Bau- und Wohnungswesen.

Behrmann, T. and A. Kathe (2004). Zur Anwendung hedonischer Methoden beim Häuserpreisindex. Wirtschaft und Statistik 5, 525-529.

Dechent, J. (2008, 1). Häuserpreisindex - Projektfortschritt und erste Ergebnisse für bestehende Wohngebäude. Wirtschaft und Statistik, $69-81$.

Demary, M. (2009). Hedonische Immobilienpreisindizes - Verfahren und Beispiele. IWTrends 3, 1-15. 
Destatis (2003). Methoden der Preis- und Volumenmessung. Fachserie 18, Reihe S. 24, Statistisches Bundesamt.

Destatis (2011). Preisindices für die Bauwirtschaft. Fachserie 17, Reihe 4, Statistisches Bundesamt.

Dübel, H.-J. and S. Iden (2008). Hedonischer Immobilienpreisindex Deutschland. Forschungsauftrag des Bundesamtes für Bauwesen und Raumordnung (BBR).

Dübel, H.-J. and S. Iden (2010). Weiterentwicklung hedonischer Verfahren zur Berechnung von Hauspreisindizes, HPX. Forschungsauftrag des Bundesamtes für Bauwesen und Raumordnung (BBR).

Georgi, S. and P. Barkow (2010). Wohnimmobilien-Indizes: Vergleich Deutschland - Großbritannien. Zentraler Immobilien Ausschuss e.V.

Girouard, N., M. Kennedy, P. van den Noord, and C. André (2006). Recent house price developments: The role of fundamentals. OECD Economics Department Working Paper, No. 475.

Hajek, S. and H. Krumrey (2011, August 8). Immer höher schrauben. Wirtschafts Woche 32, $76-87$.

Hampe, S. and F. Wenzel (2011). BulwienGesa-Immobilienindex 1975 - 2010. Technical report, BulwienGesa AG.

hei/dpa (2011, September 9). Berlin ist längst kein Mieterparadies mehr. Focus Online.

Hoffmann, J. and C. Kurz (2002). Rent indices for housing in West Germany 1985 to 1998. Working Paper Series 116, European Central Bank.

Hoffmann, J. and A. Lorenz (2006). Real estate price indices in Germany: past, present and future. OECD-IMF Workshop "Real Estate Price Indexes", Paris, November 6-7, 2006.

Kholodilin, K. A. and A. Mense (2011). Can internet ads serve as an indicator of homeownership rates? Discussion Papers of DIW Berlin 1168, DIW Berlin, German Institute for Economic Research. 
Kholodilin, K. A., J.-O. Menz, and B. Siliverstovs (2010). What drives housing prices down? Evidence from an international panel. Jahrbücher für Nationalökonomie und Statistik 230(1), 59-76.

Maurer, R., M. Pitzer, and S. Sebastian (2004). Hedonic price indices for the Paris housing market. Allgemeines Statistisches Archiv 88, 303-326.

Nappi-Choulet, I. and T.-P. Maury (2009). A spatiotemporal autoregressive price index for the Paris office property market. Real Estate Economics 37(2), 305-340.

Rousová, L. and P. van den Noord (2011). Predicting peaks and troughs in real house prices. OECD Economics Department Working Papers 882, OECD Publishing.

Schürt, A. (2010). Synopse Immobilienpreisbeobachtung in Deutschland 2010. Anforderungen - Datengrundlagen — Verfahren — Produkte. Technical report, Bundesinstitut für Bau-, Stadt- und Raumforschung.

Uken, M. (2011, September 7). Anleger entdecken das Betongold. Zeit Online. 


\section{Appendix}

Table 1: Comparison of the three databases: Immobilienscout24, Immonet, and Immowelt. Correlation with population of NUTS1 regions, July 2011

\begin{tabular}{l|cc|cc}
\hline & \multicolumn{2}{|c}{ houses } & \multicolumn{2}{c}{ flats } \\
& for sale for rent & for sale & for rent \\
& $(1)$ & $(2)$ & $(3)$ & $(4)$ \\
\hline Immonet & 0.824 & 0.913 & 0.940 & 0.643 \\
Immowelt & 0.407 & 0.914 & 0.726 & 0.692 \\
Immoscout24 & 0.946 & 0.948 & 0.933 & 0.855 \\
Cumulated $^{\text {Whole market }}{ }^{1}$ & 0.910 & 0.950 & 0.938 & 0.811 \\
\hline Whole & \multicolumn{4}{|c}{0.959} \\
\hline${ }^{1}$ Population to total number of ads, all market segments and \\
\multicolumn{2}{c}{ websites. }
\end{tabular}


Table 2: List of variables from housing ads

\begin{tabular}{l|l}
\hline Flats for rent & Flats for sale \\
\hline ID & ID \\
Bundesland & Bundesland \\
City & City \\
District & District \\
Address & Address \\
ZIP code & ZIP code \\
Location & Location \\
Area & Area \\
Usable area & Usable area \\
Cold rent & \\
Warm rent & \\
Rent for parking lot & \\
Additional costs & \\
Heating costs & Purchase price \\
& Price of parking lot \\
Type of flat & Type of flat \\
Floor & Floor \\
Number of floors & Number of floors \\
Number of rooms & Number of rooms \\
Number of bedrooms & Number of bedrooms \\
Number of bathrooms & Number of bathrooms \\
Cellar & Cellar \\
Guest WC & Guest WC \\
Use of garden & Use of garden \\
Balcony or terrace & Balcony or terrace \\
Parking lot available & Parking lot available \\
Number of parking lots & Number of parking lots \\
Fitted kitchen & Fitted kitchen \\
Elevator & Elevator \\
Accessible for handicapped & Accessible for handicapped \\
Suited for elderly & Suited for elderly \\
Pets allowed & Pets allowed \\
Year of construction & Year of construction \\
Year of last renovation & Year of last renovation \\
Condition & When vacant \\
Equipment & Condition \\
Heating & Monument \\
Type of lighting & Equipment \\
Energy performance certificate & Heating \\
Energy value & Type of lighting \\
Social lodging & Energy value \\
Rent deposit & Rental income \\
\hline
\end{tabular}


Table 3: Descriptive statistcs of ads offering flats for rent and sale

\begin{tabular}{|c|c|c|c|c|}
\hline Characteristic & Statistic & Unit of measurement & $\begin{array}{c}\text { Flats } \\
\text { for rent }\end{array}$ & $\begin{array}{c}\text { Flats } \\
\text { for sale }\end{array}$ \\
\hline Value per $m^{2}$ & average & euros & 6.80 & 2134.00 \\
\hline Area & average & $m^{2}$ & 71.57 & 86.93 \\
\hline Room & average & number of rooms & 2.52 & 2.78 \\
\hline Fitted kitchen & average & 1 if available, 0 otherwise & 0.47 & 0.40 \\
\hline Cellar & average & 1 if available, 0 otherwise & 0.49 & 0.60 \\
\hline Parking lots & average & 1 if available, 0 otherwise & 0.10 & 0.26 \\
\hline Elderly & average & 1 if available, 0 otherwise & 0.16 & 0.16 \\
\hline Elevator & average & 1 if available, 0 otherwise & 0.41 & 0.41 \\
\hline Guest WC & average & 1 if available, 0 otherwise & 0.19 & 0.24 \\
\hline Rented out & average & 1 if available, 0 otherwise & - & 0.240 \\
\hline Monument & average & 1 if available, 0 otherwise & - & 0.095 \\
\hline Handicapped & average & 1 if available, 0 otherwise & 0.168 & 0.169 \\
\hline New & average & probability $[0,1]$ & - & 0.167 \\
\hline Use of garden & average & 1 if available, 0 otherwise & 0.216 & 0.267 \\
\hline Floor 0 & share, $\%$ & & 8.1 & 12.8 \\
\hline Floor $(0,5]$ & share, $\%$ & & 83.4 & 83.1 \\
\hline Floor $(5,10]$ & share, $\%$ & & 6.8 & 3.7 \\
\hline Floor $(10,20]$ & share, $\%$ & & 1.7 & 0.3 \\
\hline Floor $(20,40]$ & share, $\%$ & & 0.0 & 0.0 \\
\hline Construction year: before 1900 & share, $\%$ & & 11.7 & 14.5 \\
\hline Construction year: $(1900,1940]$ & share, $\%$ & & 25.3 & 26.1 \\
\hline Construction year: $(1940,1960]$ & share, $\%$ & & 7.4 & 10.0 \\
\hline Construction year: $(1960,1990]$ & share, $\%$ & & 36.9 & 16.8 \\
\hline Construction year: $(1990,2000]$ & share, $\%$ & & 15.6 & 10.7 \\
\hline Construction year: after 2000 & share, $\%$ & & 3.1 & 21.9 \\
\hline Type of flat: unknown & share, $\%$ & & 9.2 & 6.5 \\
\hline Type of flat: Apartment & share, $\%$ & & 0.1 & 0.1 \\
\hline Type of flat: Dachgeschosswohnung & share, $\%$ & & 4.7 & 8.0 \\
\hline Type of flat: Erdgeschosswohnung & share, $\%$ & & 8.8 & 9.6 \\
\hline Type of flat: Etagenwohnung & share, $\%$ & & 73.8 & 64.6 \\
\hline Type of flat: Loft & share, $\%$ & & 0.3 & 0.8 \\
\hline Type of flat: Loft/Atelier & share, $\%$ & & 0.1 & 0.4 \\
\hline Type of flat: Maisonette & share, $\%$ & & 1.7 & 4.0 \\
\hline Type of flat: Penthouse & share, $\%$ & & 0.2 & 2.5 \\
\hline Type of flat: Sonstige Wohnung & share, $\%$ & & 0.4 & 0.5 \\
\hline Type of flat: Souterrain & share, $\%$ & & 0.1 & 0.2 \\
\hline Type of flat: Terrassenwohnung & share, $\%$ & & 0.8 & 2.5 \\
\hline
\end{tabular}


Table 4: Results of hedonic regression for the flats rents in Berlin, 2011:6-2012:2

\begin{tabular}{|c|c|c|c|c|}
\hline Regressor & Estimate & St. error & t-statistic & p-value \\
\hline Intercept & 6.719 & 0.107 & 62.626 & 0.000 \\
\hline Log of area & -2.084 & 0.052 & -40.334 & 0.000 \\
\hline$(\log \text { of area })^{2}$ & 0.234 & 0.006 & 37.430 & 0.000 \\
\hline Room & 0.001 & 0.001 & 1.001 & 0.317 \\
\hline Floor $(0,5]$ & 0.009 & 0.004 & 2.310 & 0.021 \\
\hline Floor $(5,10]$ & -0.016 & 0.005 & -3.049 & 0.002 \\
\hline Floor $(10,20]$ & -0.050 & 0.008 & -6.617 & 0.000 \\
\hline Floor $(20,40]$ & 0.024 & 0.036 & 0.652 & 0.514 \\
\hline Fitted kitchen & 0.064 & 0.002 & 32.030 & 0.000 \\
\hline Cellar & 0.007 & 0.002 & 3.464 & 0.001 \\
\hline Parking lots & 0.052 & 0.003 & 19.361 & 0.000 \\
\hline Elderly & -0.006 & 0.005 & -1.194 & 0.232 \\
\hline Elevator & 0.000 & 0.002 & 0.060 & 0.952 \\
\hline Guest WC & 0.002 & 0.004 & 0.648 & 0.517 \\
\hline Construction year before 1900 & -0.036 & 0.003 & -12.407 & 0.000 \\
\hline Construction year $(1940,1960]$ & -0.074 & 0.004 & -18.880 & 0.000 \\
\hline Construction year $(1960,1990]$ & -0.109 & 0.003 & -33.062 & 0.000 \\
\hline Construction year $(1990,2000]$ & 0.009 & 0.004 & 2.550 & 0.011 \\
\hline Construction year after 2000 & 0.129 & 0.006 & 22.946 & 0.000 \\
\hline Type of flat: Apartment & 0.057 & 0.035 & 1.640 & 0.101 \\
\hline Type of flat: Dachgeschosswohnung & 0.107 & 0.005 & 23.426 & 0.000 \\
\hline Type of flat: Erdgeschosswohnung & 0.021 & 0.005 & 4.005 & 0.000 \\
\hline Type of flat: Etagenwohnung & 0.029 & 0.003 & 10.465 & 0.000 \\
\hline Type of flat: Loft & 0.164 & 0.020 & 8.239 & 0.000 \\
\hline Type of flat: Loft/Atelier & 0.160 & 0.020 & 8.062 & 0.000 \\
\hline Type of flat: Maisonette & 0.093 & 0.007 & 13.387 & 0.000 \\
\hline Type of flat: Penthouse & 0.236 & 0.018 & 13.262 & 0.000 \\
\hline Type of flat: Sonstige Wohnung & 0.014 & 0.013 & 1.097 & 0.273 \\
\hline Type of flat: Souterrain & -0.031 & 0.035 & -0.890 & 0.374 \\
\hline Type of flat: Terrassenwohnung & 0.092 & 0.010 & 9.332 & 0.000 \\
\hline Handicapped & -0.038 & 0.005 & -7.790 & 0.000 \\
\hline Use of garden & 0.034 & 0.003 & 10.825 & 0.000 \\
\hline Date 2011:07 & 0.028 & 0.004 & 7.747 & 0.000 \\
\hline Date 2011:08 & 0.027 & 0.004 & 7.256 & 0.000 \\
\hline Date 2011:09 & 0.038 & 0.004 & 10.439 & 0.000 \\
\hline Date 2011:10 & 0.040 & 0.004 & 11.025 & 0.000 \\
\hline Date 2011:11 & 0.049 & 0.004 & 13.534 & 0.000 \\
\hline Date 2011:12 & 0.055 & 0.004 & 15.152 & 0.000 \\
\hline Date 2012:01 & 0.062 & 0.004 & 16.991 & 0.000 \\
\hline Date 2012:02 & 0.068 & 0.004 & 18.900 & 0.000 \\
\hline ZIP code 12627 & -0.566 & 0.011 & -50.850 & 0.000 \\
\hline 10117 & $\begin{aligned} \cdots \\
0\end{aligned}$ & $\begin{array}{c}\cdots \\
0012\end{array}$ & $\begin{array}{c}\cdots \\
5062\end{array}$ & 0 \\
\hline$N$ & \multicolumn{4}{|c|}{37,618} \\
\hline$K$ & \multicolumn{4}{|c|}{227} \\
\hline$R_{a d j}^{2}$ & \multicolumn{4}{|c|}{0.648} \\
\hline
\end{tabular}


Table 5: Results of hedonic regression for the flats prices in Berlin, 2011:6-2012:2

\begin{tabular}{|c|c|c|c|c|}
\hline Regressor & Estimate & St. error & t-statistic & p-value \\
\hline Intercept & 7.199 & 0.117 & 61.444 & 0.000 \\
\hline Log of area & 0.092 & 0.054 & 1.705 & 0.088 \\
\hline (Log of area $) \hat{2}$ & 0.006 & 0.006 & 0.995 & 0.320 \\
\hline Room & -0.004 & 0.002 & -1.750 & 0.080 \\
\hline Floor $(0,5]$ & 0.069 & 0.006 & 12.305 & 0.000 \\
\hline Floor $(5,10]$ & 0.101 & 0.009 & 10.723 & 0.000 \\
\hline Floor $(10,20]$ & 0.209 & 0.026 & 8.180 & 0.000 \\
\hline Floor $(20,40]$ & 0.062 & 0.102 & 0.611 & 0.541 \\
\hline Fitted kitchen & 0.068 & 0.003 & 22.145 & 0.000 \\
\hline Cellar & 0.021 & 0.003 & 6.827 & 0.000 \\
\hline Parking lots & 0.027 & 0.003 & 7.841 & 0.000 \\
\hline Elderly & -0.008 & 0.005 & -1.569 & 0.117 \\
\hline Elevator & 0.126 & 0.004 & 33.650 & 0.000 \\
\hline Guest WC & 0.008 & 0.004 & 1.876 & 0.061 \\
\hline Construction year before 1900 & -0.072 & 0.005 & -15.293 & 0.000 \\
\hline Construction year $(1940,1960]$ & -0.196 & 0.006 & -30.532 & 0.000 \\
\hline Construction year $(1960,1990]$ & -0.182 & 0.006 & -30.088 & 0.000 \\
\hline Construction year $(1990,2000)$ & 0.012 & 0.007 & 1.812 & 0.070 \\
\hline Construction year after 2000 & 0.162 & 0.006 & 28.439 & 0.000 \\
\hline Type of flat: Apartment & -0.029 & 0.036 & -0.787 & 0.431 \\
\hline Type of flat: Dachgeschosswohnung & 0.091 & 0.007 & 12.320 & 0.000 \\
\hline Type of flat: Erdges & 0.003 & 0.008 & 0.370 & 0.711 \\
\hline Type of flat: Etagenwohnung & 0.011 & 0.006 & 2.006 & 0.045 \\
\hline Type of flat: Loft & 0.066 & 0.017 & 3.877 & 0.000 \\
\hline Type of flat: Loft/Atelier & 0.094 & 0.020 & 4.745 & 0.000 \\
\hline Type of flat: Maisonette & 0.068 & 0.009 & 7.373 & 0.000 \\
\hline Type of flat: Penthouse & 0.182 & 0.011 & 16.738 & 0.000 \\
\hline Type of flat: Sonstige Wohnung & 0.039 & 0.020 & 1.980 & 0.048 \\
\hline Type of flat: Souterrain & -0.206 & 0.037 & -5.612 & 0.000 \\
\hline Type of flat: Terrassenwohnung & 0.076 & 0.011 & 7.110 & 0.000 \\
\hline Rented out & -0.159 & 0.004 & -44.606 & 0.000 \\
\hline Monument & 0.046 & 0.006 & 7.277 & 0.000 \\
\hline Barrierefrei & -0.026 & 0.005 & -4.886 & 0.000 \\
\hline New & 0.100 & 0.010 & 9.986 & 0.000 \\
\hline Use of garden & 0.015 & 0.004 & 3.868 & 0.000 \\
\hline Date 2011:07 & 0.020 & 0.006 & 3.208 & 0.001 \\
\hline Date 2011:08 & 0.031 & 0.006 & 5.004 & 0.000 \\
\hline Date 2011:09 & 0.034 & 0.006 & 5.426 & 0.000 \\
\hline Date 2 & 0.044 & 0.006 & 6.782 & 0.000 \\
\hline Date 2 & 0.061 & 0.006 & 9.500 & 0.000 \\
\hline Date 2011:12 & 0.085 & 0.007 & 12.976 & 0.000 \\
\hline Date 2012:01 & 0.099 & 0.007 & 15.122 & 0.000 \\
\hline Date 2012:02 & 0.100 & 0.007 & 15.331 & 0.000 \\
\hline ZIP code 10119 & 0.056 & 0.013 & 4.135 & 0.000 \\
\hline $\begin{array}{l}\cdots \\
\text { ZIP code } 12619\end{array}$ & -1164 & 0.025 & -32914 & 0.000 \\
\hline$N$ & \multicolumn{4}{|c|}{53,409} \\
\hline$K$ & \multicolumn{4}{|c|}{230} \\
\hline$R_{a d j}^{2}$ & \multicolumn{4}{|c|}{0.622} \\
\hline
\end{tabular}


Figure 1: Distribution of quality-adjusted rent for flat by Berlin's districts, February 2012

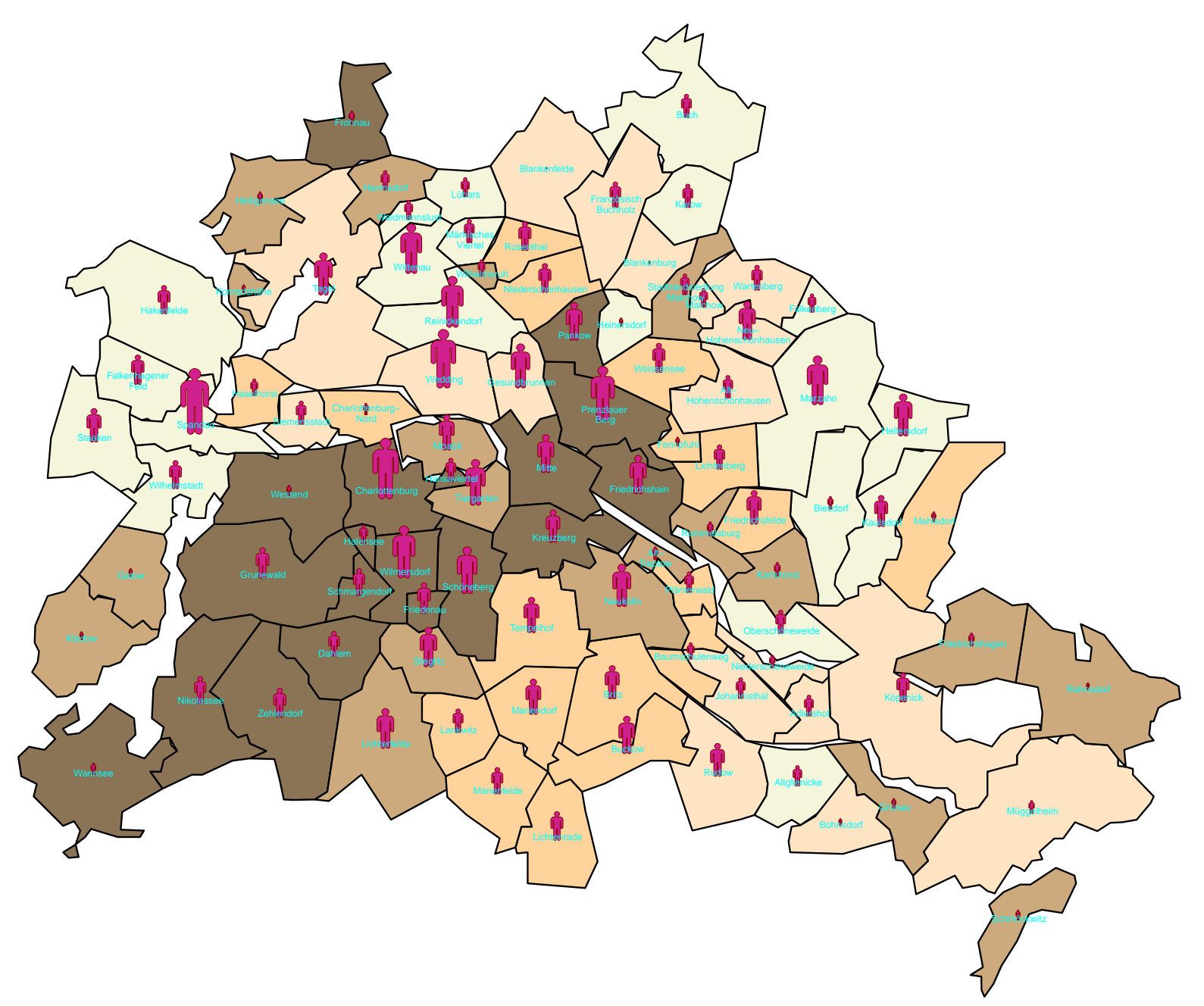

Euros per $\mathrm{m}^{2}$

$\square(4.7,5.5]$

$\square(5.5,5.8]$

$\square(5.8,6.1]$

$\square(6.1,6.7]$

$\square(6.7,8.4]$ 
Figure 2: Distribution of quality-adjusted price for flat by Berlin's districts, February 2012

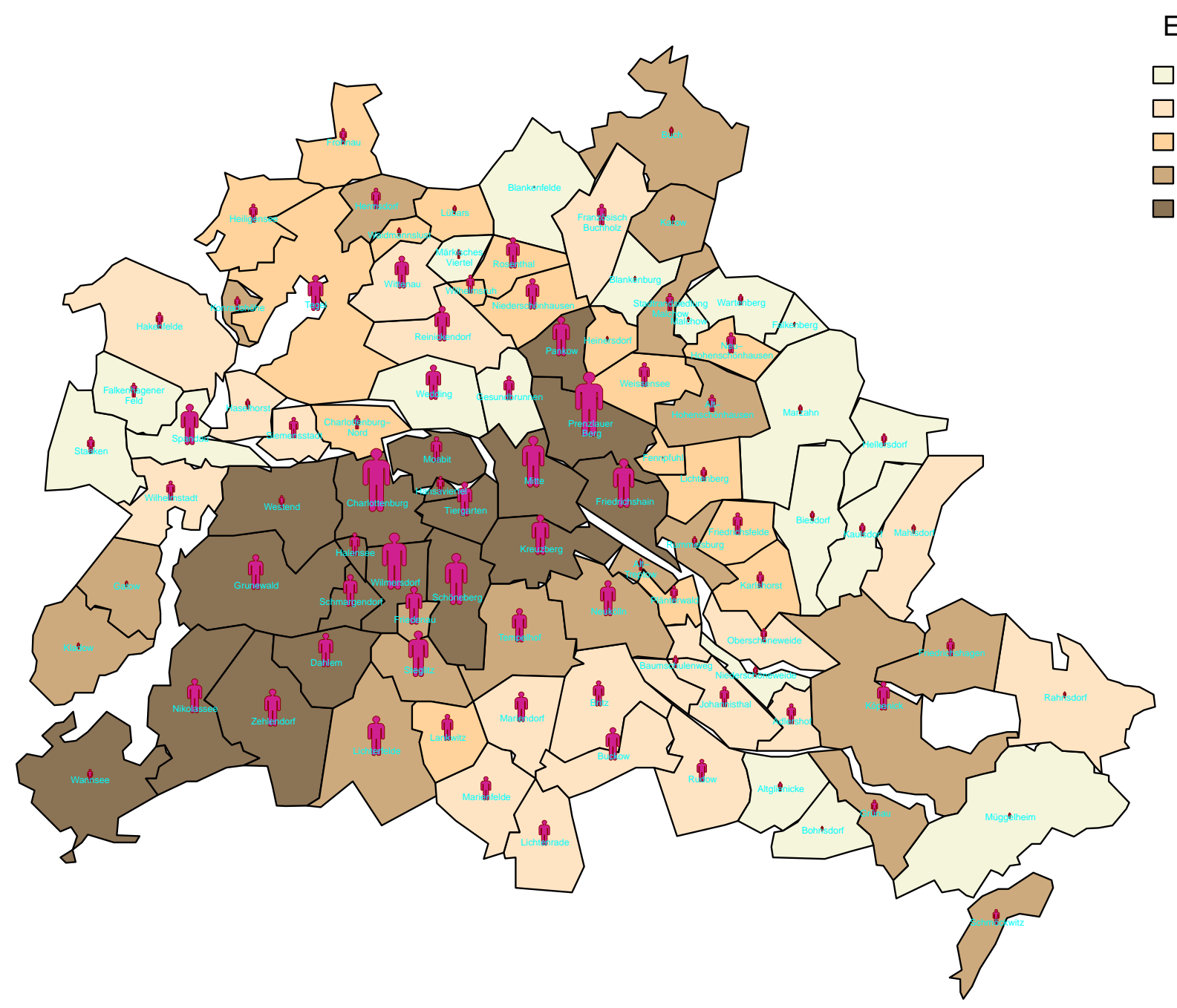

Euros per $\mathrm{m}^{2}$

$\square(838,1166]$

$\square(1166,1322]$

$\square(1322,1490]$

$\square(1490,1700]$

$\square(1700,2213]$ 
Figure 3: Dynamics of rents and prices for flats in Berlin-Mitte, June 2011 — February 2012
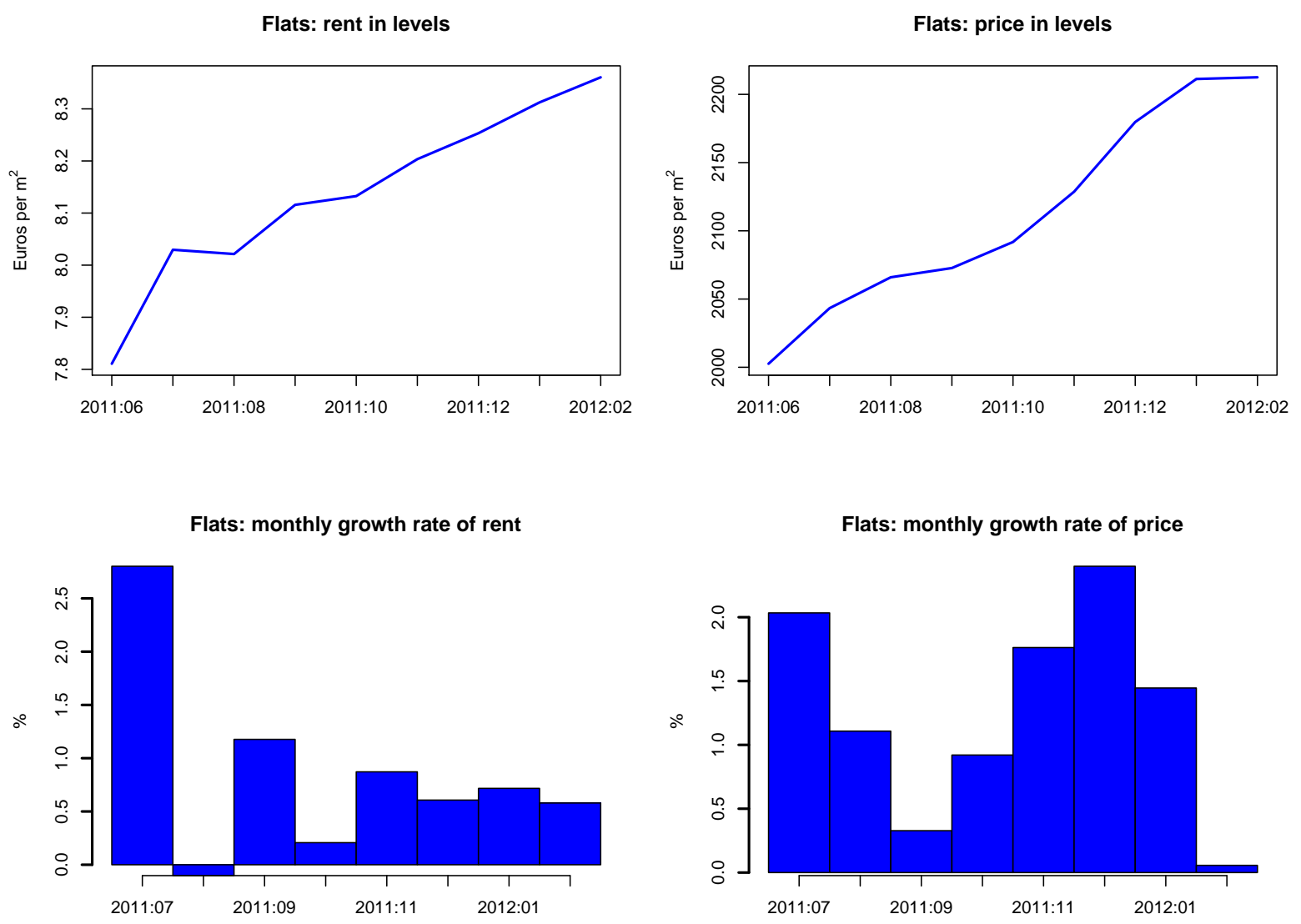